\title{
Case Report: \\ USE OF INTRA-AORTIC BALLOON PUMP (IABP) IN HIGH-RISK PERCUTANEOUS CORONARY INTERVENTION PROCEDURE
}

\author{
Yudi Her Oktaviono \\ Department of Cardiology, Faculty of Medicine \\ Universitas Airlangga, Dr. Soetomo Hospital, Surabaya
}

\begin{abstract}
ABSTRAK
Intra-aortic balloon pump (IABP) sering digunakan pada pasien yang menjalani prosedur percutaneous coronary intervention (PCI) berisiko tinggi, terutama jika dikaitkan dengan gangguan hemodinamik. Namun, perangkat ini masih kurang dimanfaatkan di sentra ini. Dalam laporan kasus ini, pasien laki-laki berusia 65 tahun dengan tiga penyakit pembuluh darah (oklusi Total kronis LAD, dan stenosis signifikan sirkumfleks kiri dan arteri koroner kanan), fraksi ejeksi yang rendah dan tekanan darah prosedur pra, dilaporkan telah menggunakan dukungan IABP sebelum PCI. Intervensi menembus LAD yang tersumbat tidak berhasil. Setelah tindakan, pasien diperiksa di unit perawatan intensif. Pelepasan IABP dilakukan setelah penggunaan sekitar 30 jam, tanpa komplikasi. (FMI 2015;51:196-202)
\end{abstract}

Kata kunci: PCI risiko tinggi, IABP, intra-aortic counterpulsation

\begin{abstract}
Intra-aortic balloon pump (IABP) is often used in patients who undergo high risk percutaneous coronary intervention (PCI) procedures, particularly if associated with hemodynamic impairment. However, this device is still underused in this center. In this case report, a 65-year old male patient with triple vessel disease (chronic total occluded left anterior descending artery-LAD, and significant stenoses of left circumflex and right coronary arteries), low ejection fraction and preprocedure blood pressure, was reported to have IABP support applied before PCI. The intervention to penetrate the occluded LAD was not success. After procedure, the patient was observed in intensive care unit. Weaning of IABP was performed after about 30 hours usage, without complication.(FMI 2015;51:196-202)
\end{abstract}

Keywords: high risk PCI, IABP, intra-aortic counterpulsation

Correspondence: Yudi Her Oktaviono, Departement of Cardiology, Faculty of Medicine, Universitas Airlangga, Dr. Soetomo Hospital, J1. Mayjen Prof. Dr. Mustopo 6 - 8, Surabaya, East Java, Indonesia. e-mail: yhoktaviono@yahoo.com. Phone: 62-31-5501701

\section{INTRODUCTION}

Intra-aortic balloon pump (IABP) is a method of transient mechanical circulatory support trying to create a better balance between oxygen supply and demand to the heart muscle using the concept of systolic unloading and diastolic augmentation. As a result, cardiac output, ejection fraction, and coronary perfusion increase in line with the decrease in left ventricular wall stress, systemic resistance, and systemic and pulmonary capillary wedge pressure (McPherson 2010). Diastolic augmentation concept was firstly introduced by Kantrowitz brothers in 1953, before finally IABP was firstly used clinically in patients with cardiogenic shock in 1968 (Kantrowitz et al 1968). IABP early generation used 15 Fr catheter, and required a surgical approach for its installation and disposal. In 1979, Datascope Corporation firstly introduced IABP percutaneously, with a number of changes and new technologies, which made the indication and application of IABP wider and make the number of
IABP installation in catheterization laboratory increased compared to that of surgical installation (Mulukutla et al 2010). National Center of Health Statistics estimates that as many as 42,000 cases of IABP were used in 2002 in the United States (Krishna \& Zacharowski 2009). ACC/AHA Guidelines on STEMI suggests that the use of IABP in cardiogenic shock is included in calss IB recommend-ation (Antman et al 2004). Although the benefits IABP installation in indicateds condition has been suggested by the guide-lines, but the frequency of use of IABP in Dr. Soetomo Hospital is still low. This paper discusses a case of IABP use in high-risk PCI procedure.

\section{CASE REPORT}

Mr. AL, 65 years old, with clinically stable angina, and laboratory results within normal limits. ECG showed sinus rhythm $80 \mathrm{x} / \mathrm{m}$, axis deviation to the left, complete 
left branch bundle block and old inferior infarction. Cardiomegaly was obtained with $63 \%$ CTR. The results of echocardiography showed decreased ejection fraction (30\%, by mod A4C) with left ventricular segmental analysis. Hypokinetic was found in the lateral (B), posterior (B) and inferior (B) segments and severe hypokinetic weight in other segments.

The results of previous coronary angiography showed total chronic occlusion (CTO) in osteal LAD (left anteror descending artery), stenosis of $75 \%$ in the proximal Cx (left cirumflex artery) after OM1 (obtuse marginal branch), as well as the presence of diffuse lesions up to $90 \%$ in mid and distal RCA (right coronary artery), providing collateral to the LAD. Patients received therapy of cardioaspirin tablet $1 \mathrm{x} 1,1 \mathrm{x}$ clopidogrel $75 \mathrm{mg}$, simvastatin $20 \mathrm{mg} \mathrm{1x,} \mathrm{1x} \mathrm{irbesartan} 300 \mathrm{mg}$, $0.25 \mathrm{mg}$ digoxin $1 \mathrm{x}$, and ISDN tablet if necessary.

The patient was planned for PCI to penetrate CTO in LAD. Because the hemodynamic was not optimal (BP $85 / 63 \mathrm{~mm} \mathrm{Hg}$ ), IABP was installed prior to PCI in the ratio $1: 1$ after being given with dopamine $5 \mathrm{ug} / \mathrm{kg} / \mathrm{m}$. CTO was not penetrated, PCI was discontinued, the patient was observed in ICCU assisted by IABP backup. The next day, with BP $115 / 78 \mathrm{mmHg}$ (after dopamine was released), and urine production $1150 \mathrm{cc} / 24$ hours, IABP weaning was performed to a ratio of $1: 2$ and the next 1 hour 1: 4 , then stopped after about 28 hours of use. The patient was allowed to go home with stable hemodynamic one day later.

\section{DISCUSSION}

Ferguson et al (2001) reported that in 4-year period (1996-2000), 203 hospitals in various countries (90\% in the USA) recorded that IABP was installed in more than 16 thousand patients, and the mortality associated with IABP was approximately $0.05 \%$. The main indication of IABP installation was for support and hemodynamic stabilization, while the most frequent place of installation was in the catheterization laboratory. Another place often performed IABP installation was the operating room (Ferguson et al 2001)

\section{Instrument description}

IABP instrument consisted of a double lumen catheter of 7.5Fr-9.9Fr with a balloon 25-50 cc at its distal end and a cable connecting it to a pump that pumps helium into the balloon (Mulukutla et al 2010). Two companies that provide these tools are Datascope and Arrow. There are three sizes of the balloons that are often used: $30 \mathrm{cc}$ (height 147-162 cm), $40 \mathrm{cc}$ (height $162-182 \mathrm{~cm}$ ) and 50 cc (height> $182 \mathrm{~cm}$ ). The balloon is inserted into the aorta, placed between the subclavian artery and renal artery (McPherson 2012) In these patients machine used was Arrow IABP with balloon size $40 \mathrm{cc}$ (patient's height $166 \mathrm{~cm}$ ). Prior to the installation of IABP, vascular conditions must be examined thoroughly. Inspection includes pulse palpat-ion in lower extremities from proximal to distal and auscultation is performed in the lower abdomen and the femoral artery (Santa-cruz et al 2006). Patients in this case had a good vascular conditions.

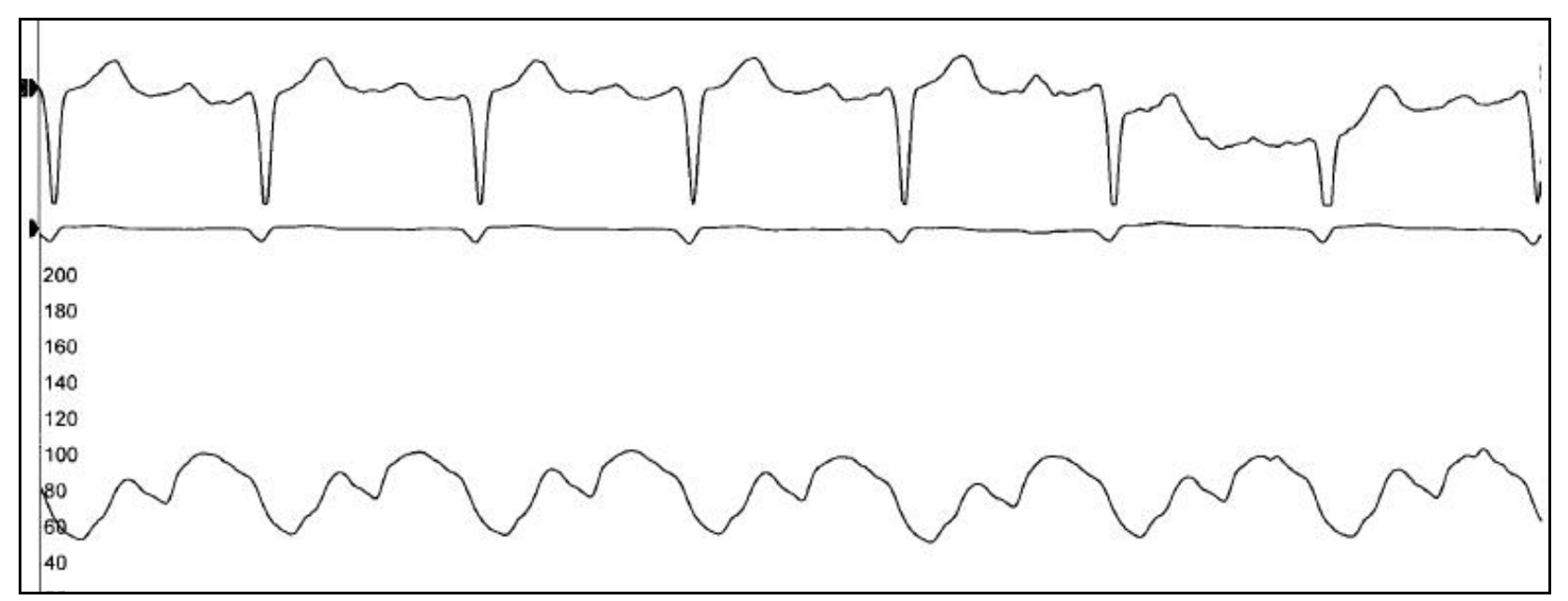

Figure 1 . Hemodynamic curve after IABP installation 

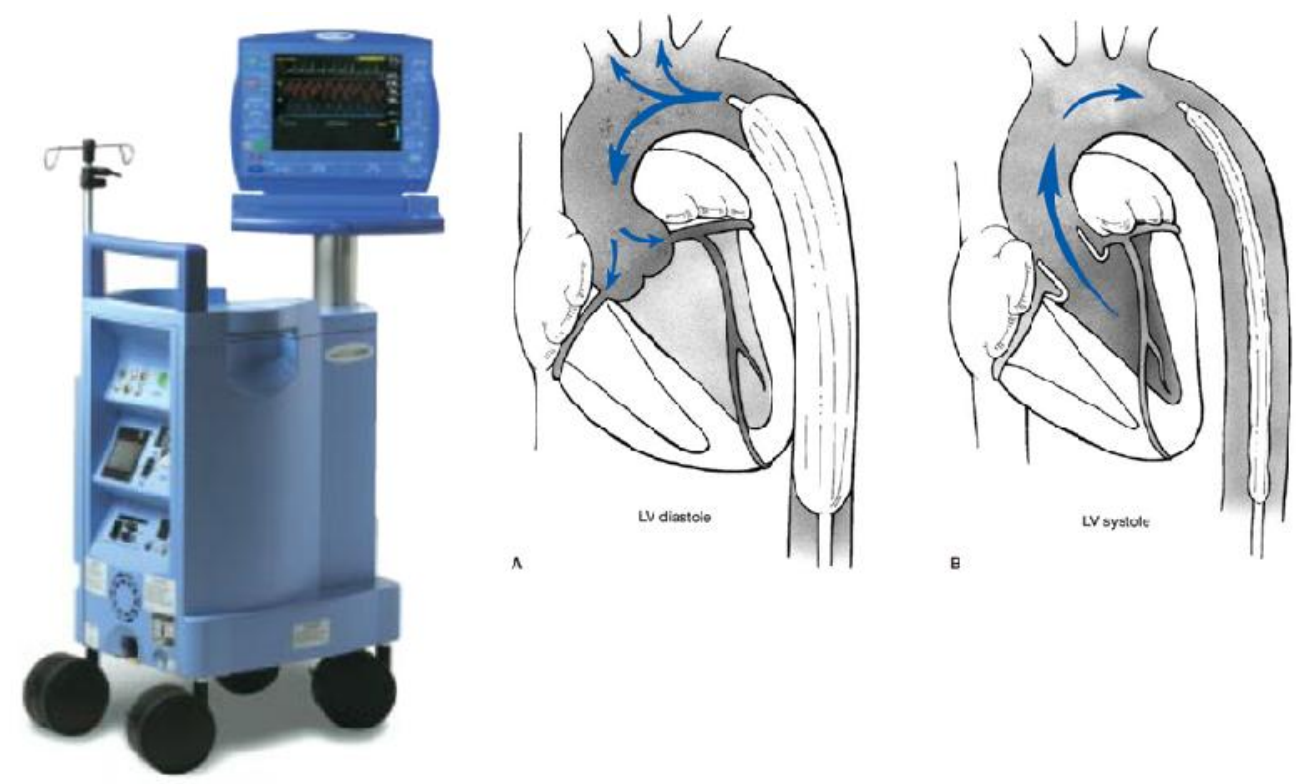

Figure 2. Left: IABP machine (arrow); Right: inflation (diastolic phase) and deflation (systolic phase) of IABP balloon (McGee et al 2007)

\section{Indication}

IABP is performed as therapy in conditions of acute myocardial infarction, cardiogenic shock, MR and VSD acute, catheterization and angioplasty, refractory unstable angina, refractory $\mathrm{LV}$ failure, refractory ventricular arrhythmias, cardiomyopathy, sepsis, cardiac surgery, weaning from kardiopulmonary bypass, and on infan and children with complex cardiac anomalies (Stone et al 2003, Krishna \& Zacharowski 2009). For heart surgery, IABP can be installed before surgery or during surgery when weaning difficulties occur from the cardiopulmonary bypass machine (McGee et al 2007). Advances in catheter technology and catheterization techniques have allowed patients with high risk (low $\mathrm{EF}$, multivessel disease, left main stenosis and hemodynamic instability) with significant comorbidities to undergo revascular-ization. Hemodynamic support and increase coronary perfusion by IABP will provide benefits for these patients while undergoing the procedure (Santa-cruz et al 2006). In these patients, high risk PCI with decreased hemodynamic function is the reason the use of IABP.

Contraindications of IABP procedure is aortic regurgitation, aortic dissection, heart disease, possibly improved chronic end-stage, and aortic stenting. Relative contraindications are uncontrolled sepsis, abdominal aortic aneurysm, tachyarrhythmia, severe peripheral vascular disease and reconstructive surgery of the large arteries (Stone et al 2003, Krishna \& Zacharowski 2009)

\section{Mechanical installation}

Registry data showed that IABP is $98 \%$ percutaneously, and $2 \%$ surgically installed. $65 \%$ used catheter sized $9,5 \mathrm{~F}$, while the rest use a $8 \mathrm{~F}$ catheter. $80 \%$ of the patients used sheath in its installation, 20\% installed sheathlessly (Stone et al 2003). Mechanical sheathless is particularly for cases with severe femoral artery calcification, obesity, and diseases ileofemoral (Santacruz et al 2006). In this case IABP was installed using a sheath.

When the installation is done percutaneously, after local anesthesia, femoral artery puncture was done in Seldinger's technique. Wire, dilator, sheath and balloon were installed under fluoroscopic guidance. Once the balloon is in intended place, the console is connected to IABP machine for setting and pump initiation. When it is done surgically, incision is performed in inguinal area until femoral artery is exposed under local anesthesia, after which the femoral artery is incised, wiring is done, and remaning is almost the same. If it is installed during open heart, installation can be done directly from the ascending aorta (McGee et al 2007). In these cases, IABP is installed percutaneouslu on left femoral artery at catheterization laboratory. 


\section{Timing}

The timing of balloon inflation and deflation related to cardiac cycle is essential for optimal functioning. Balloon inflation should occur immediately after the closing of the aortic valve, represented by dicrotic notch on arterial waveform. Delayed inflation or too fast deflation can interfere with anterograde blood flow and increasing afterload. To be able to synchronize balloon operation with heart contractions, we may be use ECG or arterial pressure wave to trigger the IABP. Although IABP is very effective on a regular intrinsic rhythm, technological developments have made adaptations to pulse rhythm of runways and compensation for irregular rhythm (Stenz 2006).

IABP is usually run with a pump ratio of $1: 1$ (each heart contraction is followed by balloon inflation and deflation). In cases where the heart rate is more than $100 / \mathrm{m}$ assistance ratio of $1: 2$ can be more effective (Stenz 2006). Average duration of hemodynamic support is 53 hours (Ferguson et al 2001). In other registry report, Stone et al (2003) reported average IABP duration of $3.2+2.2$ days (median 3 days, range 1-42 days) (Stone et al 2003). In these patients, IABP is installed for about 30 hours.

\section{Hemodynamic effects}

From hemodynamic and physiological standpoint, intraaortic pressure drop during systolic leads to reduced afterload, while the increase of aortic pressure ny the balloon during diastolic improves coronary flow. Therefore it can be postulated that balloon pump deflatin reduces afterload, increases stroke volume, lower end-diastolic volume, and decrease myocardial oxygen consumption, while IABP development increases blood flow to the coronary and oxygen supply, improves cardiac output, reducing end-diastolic volume and reducing end-diastolic pressure, which overall reduces myocardial oxygen consumption. Despite having haemodynamic and physiological benefits, the use of IABP did not provide improvement to the ejection fraction (Krishna \& Zacharowski 2009, Mulukutla et al 2010)

Hematologically, the use of IABP can induce complications as a result of mechanical damage of erythrocyte hemolysis and bleeding at the site of vascular access. Thrombocytopenia can occur due to mechanical or platelet destruction because of heparin use, so it is necessary to check $\mathrm{Hb}$, Hct and platelets every day during the use of IABP (Trost \& Hillis 2006)

\section{Monitoring and maintenance}

Chest X-ray examination should be performed every day to ensure the IABP is in place and functioning optimally (Santa-cruz et al 2006). Ideally IABP balloon tip was placed $2-3 \mathrm{~cm}$ distal from the base of the left subclavian artery. The exact position will minimize the risk of embolization to the brain and the left subclavian artery occlusion. IABP tip placement should use carina landmarks, $2 \mathrm{~cm}$ higher up, (when we draw horizontal lines) will provide IABP tip distance - the base of left subclavian artery approximately 1.5 to $3.5 \mathrm{~cm}$. In thoracic x-ray, karina structure is clearly visible, and have a consistent relationship with the aortic arch. While the use of aortic knob as guides often imposes less consistent definition since it provides wide reflection on chest $\mathrm{x}$-ray ( $\mathrm{Kim}$ et al 2007). Another practical way to determine the location of the left subclavian artery branching is to use the second ribs as guidance, while the branching of left and right renal artery is located approximately between first and second lumbar vertebrae corpus (McPherson 2012). The IABP Arrow installation guides IABP mention traits that are in place: tip location of between the second and third ICS, left radial/ulnar pulses is palpable and adequate urine production (Arrow International 2005).

\section{Anticoagulation}

Anticoagulant purposes when using IABP has been reviewed by Jiang et al (2003). From studies involving 153 patients using IABP, there was no significant difference in terms of vascular complications or laboratory end-points between the groups using continuous infusion of heparin with those not using (Jiang et al 2003). Guidelines issued by IABP factory itself does not require anticoagulation, especially when IABP is used at a ratio of $1: 1$. This time it is reasonable to use anticoagulation in patients without contraindications and when the planned IABP use more than 24 hours or with a lower assists ratio (Santa-cruz et al 2006). When given heparin, either intermittent or bolus, it is targeted to achieve partial thromboplastin time (PTT) 60-80 seconds or activated clotting time (ACT) 1.5-2 times than normal (McPherson 2012). Guidelines issued by Arrow and Datascope mentions that the use of heparin in the flush bag is in accordance with the hospital's policy. To ensure the line patency, it is advised to carry on continuous flush $3 \mathrm{cc} / \mathrm{hour}$ (Arrow International 2005, Maquet Getinge Group 2009). 

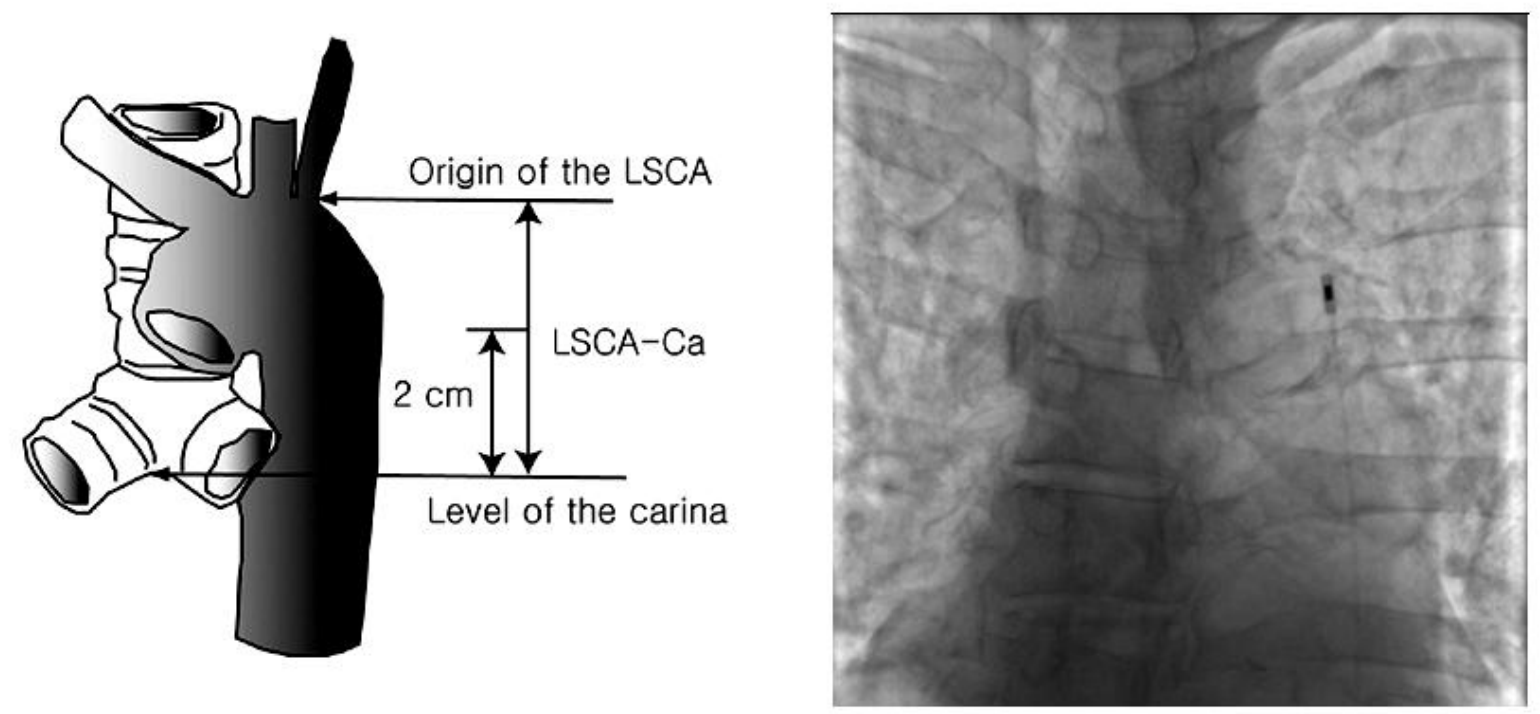

Figure 3. Location of suggested IABP tip position, $2 \mathrm{~cm}$ above the carina (left) (Kim et al 2007) and the location of IABP tip in this case (right)

\section{Weaning}

IABP weaning should be gradual. There are two ways to do: ratio reduction (an approach most commonly done) or reduction in baloon volume. It is not known which approach is superior because each technique has its advantages and disadvantages. Indications of IABP support weaning is primarily determined by the improvement of the patient's condition, which is indicated by the disappearance of ischemia and cardiac output and adequate blood pressure (Stenz 2006). Weaning usually done on a ratio of $1: 1$ to $1: 2$ and $1: 3$ within a few hours. If the patient can adapt to a ratio of 1:3, IABP can be removed (Santa-cruz et al 2006). Some of the indicators to be used in determining the IABP weaning are, among others, :1) the ratio of the assisting pump $1: 3$ or $1: 4 ; 2$ ) the use of inotropes is minimal or not at all; 3 ) cardiac output index $>2.0 \mathrm{~L} / \mathrm{min} / \mathrm{m} 2$; 4) systolic blood pressure $>100 \mathrm{mmHg}$; 5) left atrial pressure or PCWP $<10-15$ $\mathrm{mmHg}$; 6) urine production $>30 \mathrm{ml} /$ hour; 7) no angina; 8) no change ischemia on ECG; 9) no new ventricular arrhythmias (Richenbacher 1999). In these patients, prior to weaning, TD $115 / 78 \mathrm{mmHg}$ was obtained (after dopamine was released), and urine production was 1150 cc/24 hours. Pump weaning ratio was made from 1:1 to $1: 2$ and $1: 4$, then the pump was stopped.

\section{Balloon removal}

To remove the IABP, after the balloon is deflated, the leg veins was monitored with Doppler (or palpation). The distal portion of the insertion site was pressed with hand until the Doppler sound disappears. The catheter was then removed as a unit together with the sheath (when using a sheath) and blood were left a little out of the insertion site. This procedure will let out proximal thrombi and prevent flow into superficial and deep femoral artery, thus reducing the risk of distal embolization. With the other hand, proximal insertion site is pressed to stop the bleeding. When the bleeding stops, the pressure by hand is replaced with a static instrument or manual that provides continuous pressure about 30 minutes, giving the flow to the distal as monitored with Doppler (Rodigas \& Finnegan 1985, Santa-cruz et al 2006). Furthermore, pressure is given with sandbag of 5-10 $\mathrm{lb}$ for 8 hours and ensuring the ipsilateral leg is not moved. If IABP placed surgically through femoral artery (open technique), it must be reincised returned to remove the IABP with a technique similar to percutaneous method, then the femoral artery repair is done. Open technique also becomes an option if there is acute lower limb ischemia during IABP use. If the appliance is installed via the ascending aorta during open heart, it reopening and repeat sternotomy should be done in the operating room (Richenbacher 1999). In this patient the release of the tool was done percutaneously.

\section{IABP benefits for the outcome}

Various data are still controversial about the benefit of IABP on the patients' outcome. Although the ACC/AHA Task Force has suggested the use of IABP in cardiogenic shock as a class I indication since 1990, but this recommendation is more dominated by hemodynamics and physiological consideration, rather than 
the results of clinical observations or data randomization (Mulukutla et al 2010)

In GUSTO (Global Utilization of Streptokinase and Tissue Plasminogen Activator for Occluded Coronary Arteries) study, for example, after the adjustment of the status of cardiac catheterization and revascularization, no significant correlation was found between the use of IABP with mortality (Mulukutla et al 2010). A systematic analysis and a meta-analysis of the use of IABP in STEMI published in the European Heart Journal in 2009 concluded that there are no sufficient data to endorse IABP use in STEMI with cardiogenic shock (Sjauw et al 2009).

Perera et al reported that use of the IABP routinely in high risk patients (severe left ventricular dysfunction and extensive coronary disease) does not relieve MACCE (major adverse cardiac and cardiovascular events) when patients are discharged from the hospital and six months later in a RCI involving 301 patients in the United Kingdom (Perera et al 2010). This observation is supported a study by CRISP AMI (the Counterpulsation to Reduce Infarct Size Pre-PCI Acute Myocardial Infarction), published in February 2011, which concluded that the installation of IABP in 337 patients with anterior myocardial infarction without shock cardiogenic, subjected to primary PCI in 9 countries, does not reduce the extent of infarct area, compared to patients who only received primary PCI alone (Patel et al 2011). However, the use of IABP in STEMI patients with cardiogenic shock remains have a place (Ndrepepa \& Kastrati 2011)

Of the few studies that support the benefits of IABP for the outcome, SHOCK (Should we emergently revascularize Occluded Coronaries for cardiogenic shock) trial, involving 36 centers, showed that patients with AMI with thrombolytic receiving IABP had mortality rate during the treatment lower than those who did not receive IABP $(50 \%$ vs $72 \%$, p <0.0001). Furthermore, this significant difference in mortality rate was also seen in four groups of different treatment: thrombolytic therapy + IABP $(47 \%)$, IABP alone (52\%), thrombolytic alone $(63 \%)$, without thrombolytics and IABP (77\%) (Sanborn et al 2000).

\section{Complications}

Vascular complications associated mounting IABP can be major complications (ischemia of the lower limbs, acute perforation of the aorta or peripheral arteries, aortic dissection, fasciotomy to limb amputations) and minor complications minor (hematoma local, infection and ischemia is reversible with the removal of the sheath) (Meharwal \& Trehan 2002). IABP failure was reported by $2.3 \%$, with a balloon-related causes leakage (52\%), less inflation (21.7\%), insertion difficulties (13\%), and poor augmentation (39\%) (Ferguson et al 2001). This patient did not show complications in IABP installation.

\section{CONCLUSION}

We report a case of intraaortic balloon pump (IABP) use in a high risk PCI patient. This patient had triple vessel disease with reduced ejection fraction and unfavorable hemodynamic. After IABP installation, the patient's hemodynamic improved. Although PCI procedure was not successful, IABP was maintained and the patient was observed in the ICCU. IABP is was released after about 30 hours, with no complications.

\section{REFERENCES}

Antman EM, Anbe DT, Armstrong PW, Bates ER, Green LA, Hand M, Hochman JS, Krumholz HM, Kushner FG, Lamas GA, Mullany CJ, Ornato JP, Pearle DL, Sloan MA, Smith SC Jr, Alpert JS, Anderson JL, Faxon DP, Fuster V, Gibbons RJ, Gregoratos G, Halperin JL, Hiratzka LF, Hunt SA, Jacobs AK; American College of Cardiology/ American Heart Association Task Force on Practice Guidelines (Writing Committee to Revise the 1999 Guidelines for the Management of Patients With Acute Myocardial Infarction) (2004). ACC/AHA guidelines for the management of patients with STelevation myocardial infarction--executive summary: a report of the American College of Cardiology/American Heart Association Task Force on Practice Guidelines (Writing Committee to Revise the 1999 Guidelines for the Management of Patients With Acute Myocardial Infarction). Circulation 110, 588636

Arrow International (2005). Counterpulsation applied: an introduction to intra-aortic balloon pumping. Available from http://www.arrowintl.com/documents/ pdf/education/abt-tg0605.pdf. Accessed May 13, 2014

Ferguson JJ 3rd, Cohen M, Freedman RJ Jr, Stone GW, Miller MF, Joseph DL, Ohman EM (2001). The current practice of intra-aortic balloon counterpulsation: results from the Benchmark Registry. J Am Coll Cardiol 38, 1456-1462

Jiang CY, Zhao LL, Wang JA, Mohammod B (2003). Anticoagulation therapy in intra-aortic balloon counterpulsation: does IABP really need anticoagulation? J Zhejiang Univ Sci 4, 607-611

Kantrowitz A, Tjonneland S, Freed PS, Phillips SJ, Butner AN, Sherman JL Jr (1968). Initial clinical 
experience with intraaortic balloon pumping in cardiogenic shock. JAMA 203, 113-118

Kim JT, Lee JR, Kim JK, Yoon SZ, Jeon Y, Bahk JH, Kim KB, Kim CS, Lim YJ, Kim HS, Kim SD (2007). The carina as a useful radiographic landmark for positioning the intraaortic balloon pump. Anesth Analg 105, 735-738

Krishna M and Zacharowski K (2009). Principles of intra-aortic balloon pump counterpulsation. Continuing Education in Anaesthesia, Critical Care \& Pain 9, 24-28

Maquet Getinge Group (2009). Clinical support services: theory and techniques of IAB counterpulsation therapy - CS300. Available from http://ca.maquet.com/file_assets/educational-materials /en/cs300-theory-and-techniques-en.pdf. Accessed May 20, 2014

McGee Jr EC, McCarthy PM, et al (2007). Temporary circulatory mechanical support. In: Cohn LH (ed). Cardiac Surgery in the Adults, 3rd edition. New York, McGrawHill, p 507-533

McPherson JA (2010, August 26th). "Intra-aortic Balloon Counterpulsation." from : http://emedicine. medscape.com.

McPherson JA (2012). "Intra-aortic Balloon Counterpulsation" , from http://emedicine.medscape. com.

Meharwal ZS and Trehan N (2002). Vascular complications of intra-aortic balloon insertion in patients undergoing coronary reavscularization: analysis of 911 cases. Eur J Cardiothorac Surg 21, 741-747

Mulukutla S, Schneider L, et al (2010). Percutaneous Mechanical Assist Devices. In: Feldman AM (ed). Heart Failure: Device Management. West Sussex-UK, Wiley-Blackwell, p 120-124

Ndrepepa G and Kastrati A (2011). Need for critical reappraisal of intra-aortic balloon counterpulsation. JAMA 306, 1376-1377

Patel MR, Smalling RW, Thiele H, Barnhart HX, Zhou Y, Chandra P, Chew D, Cohen M, French J, Perera D, Ohman EM (2011). Intra-aortic balloon counterpulsation and infarct size in patients with acute anterior myocardial infarction without shock: the CRISP AMI randomized trial. JAMA 306, 1329-1337

Perera D, Stables R, Thomas M, Booth J, Pitt M, Blackman D, de Belder A, Redwood S; BCIS-1 Investigators (2010). Elective intra-aortic balloon counterpulsation during high-risk percutaneous coronary intervention: a randomized controlled trial. JAMA 304, 867-874

Richenbacher WE (1999). Mechanical Circulatory Support, 1st edition. Florida, CRC Press, p 44-65

Rodigas PC and Finnegan JO (1985). Technique for removal of percutaneously placed intraaortic balloons. Ann Thorac Surg 40, 80-81

Sanborn TA, Sleeper LA, Bates ER, Jacobs AK, Boland J, French JK, Dens J, Dzavik V, Palmeri ST, Webb JG, Goldberger M, Hochman JS (2000). Impact of thrombolysis, intra-aortic balloon pump counterpulsation, and their combination in cardiogenic shock complicating acute myocardial infarction: a report from the SHOCK Trial Registry. SHould we emergently revascularize Occluded Coronaries for cardiogenic shocK? J Am Coll Cardiol 36, 1123-1129

Santa-Cruz RA, Cohen MG, Ohman EM (2006). Aortic counterpulsation: a review of the hemodynamic effects and indications for use. Catheter Cardiovasc Interv 67, 68-77

Sjauw KD, Engström AE, Vis MM, van der Schaaf RJ, Baan J Jr, Koch KT, de Winter RJ, Piek JJ, Tijssen JG, Henriques JP (2009). A systematic review and meta-analysis of intra-aortic balloon pump therapy in ST-elevation myocardial infarction: should we change the guidelines? Eur Heart J 30, 459-468

Stenz R (2006). Intra-aortic balloon counterpulsation. Anaesthesia \& Intensive Care Medicine 7, 335-336

Stone GW, Ohman EM, Miller MF, Joseph DL, Christenson JT, Cohen M, Urban PM, Reddy RC, Freedman RJ, Staman KL, Ferguson JJ 3rd (2003). Contemporary utilization and outcomes of intra-aortic balloon counterpulsation in acute myocardial infarction: the benchmark registry. J Am Coll Cardiol 41, 1940-1945

Trost JC and Hillis LD (2006). Intra-aortic balloon counterpulsation. Am J Cardiol 97, 1391-1398 